\title{
Mite species (Acari: Mesostigmata) new and rare to Polish fauna, inhabiting the soil of broadleaved forests dominated by small-leaved lime (Tilia cordata Mill.) in Kwidzyn Forest District (N Poland)
}

\author{
KATARZYNA FALEŃCZYK-KOZIRÓG ${ }^{1}$, TOMASZ MARQUARDT ${ }^{1}$ \\ and SŁAWOMIR KACZMAREK ${ }^{1}$ \\ ${ }^{1}$ Kazimierz Wielki University, Institute of Environmental Biology, Department of Zoology, \\ Ossolińskich 12, 85-094 Bydgoszcz, Poland
}

Corresponding author: Katarzyna Faleńczyk-Koziróg, kasia.fk@ukw.edu.pl

(Received on 18 November 2011; Accepted on 14 April 2014)

\begin{abstract}
During a two-year study on mites of the order Mesostigmata in broadleaved forest stands dominated by small-leaved lime (Tilia cordata Mill.), 117 mite species were identified. Among them, 3 had been so far rarely recorded in Poland (Haemogamasus nidi, Stylochirus rovenensis and Eugamasus crassitarsis) and 2 were classified as new to the Polish fauna (Veigaia sibirica and Digamasellus perpusillus).
\end{abstract}

Keywords: Acari, Mesostigmata, new species, rare species, Polish fauna

\section{INTRODUCTION}

The Mesostigmata include approximately 8000 mite species that have been described to date and found in all the continents and climatic zones (HALlan 2011). Those mites inhabit mostly the soil, especially within the hemiedaphic zone. Apart from soil dwellers, some mesostigmatids live on plants or are scavengers, ectoparasites or endoparasites of vertebrates or invertebrates. In Poland, 824 Mesostigmata species were recorded by BoGDANOWICZ et al. (2008).

This paper presents the ecology and occurrence of rare species of Mesostigmata (some of them new to the Polish fauna) within broadleaved forest stands in northern Poland. Among the 117 species recorded in the study area, 3 are rare in Poland, and 2 are new to the Polish fauna. 


\section{STUDY AREA}

The study was performed in Kwidzyn Forest District, within the limits of Iława Lake District and Kwidzyn Valley (KonDRACKi 2009). We investigated 6 forest stands of various ages $(16,35,57,80,102$, and 125 years old), all dominated by smallleaved lime (Tilia cordata Mill.) and classified as the plant association Tilio-Carpinetum Tracz., 1962 (subcontinental broadleaved forest).

\section{MATERIAL AND METHODS}

Samples for research were collected in autumn (2006 and 2007) and spring (2007 and 2008). There were 100 samples $\left(50 \mathrm{~cm}^{3}\right.$ each) collected from each plot: 20 samples from the litter horizon (labelled as L) and 20 from each of the 4 artificially designated organomineral levels (labelled as subscripted OM) that were $5 \mathrm{~cm}$ thick, to the depth of $20 \mathrm{~cm}$. The number next to 'plot' indicates the age of the forest stand.

Overall, 2400 samples were collected, and after a 6-day extraction in Tullgren funnels, 25995 mites were obtained from the samples. These included $4272 \mathrm{Me}-$ sostigmata, which were identified to the species level, including all the developmental forms $(\mathrm{D}=$ deutonymph; $q=$ female; $\hat{\delta}=$ male $)$.

\section{RESULTS AND DISCUSSION}

Within the study area, Veigaia sibirica and Digamasellus perpusillus were new to the Polish fauna.

Family: Veigaiidae Oudemans, 1939

\section{Veigaia sibirica Bregetova, 1961}

Samples in which the species occurred: plot 57, $\mathrm{OM}_{1}-1$ ㅇ.

Veigaia sibirica was previously found exclusively in the soil and litter in the former Soviet Union (BREGETOVA 1977).

Family: Digamasellidae

Digamasellus perpusillus Berlese, 1905 = Digamasellus punctum Berlese 1904

Samples in which the species occurred: plot 57, $\mathrm{OM}_{3}-1$. .

Digamasellus perpusillus is considered to be in a phoretic relationship with beetles of the genus Geotrupes and previously occurred frequently in manure, compost, and decomposing organic matter: in the former Soviet Union (BREgetova 1977), Germany (KARG 1993), and United States (KRANTZ \& WALTER 2009). Its presence in the studied soil sample from a broadleaved forest is most probably accidental.

Rare species in the Polish fauna within the study area were: Haemogamasus nidi, Stylochirus rovenensis, and Eugamasus crassitarsis.

Family: Laelapidae

\section{Haemogamasus nidi (Michael, 1892)}

Samples in which the species occurred: plot 80, $\mathrm{L}$ and $\mathrm{OM}_{4}-2$. 
Haemogamasus nidi is clearly associated with small mammals, especially rodents, and their nests. It was previously recorded on e.g. Myodes rutilus, M. glareolus, Microtus oeconomus, M. arvalis, M. subterraneus, M. gregalis, Mus spicilegus, M. musculus, Apodemus sylvaticus, A. flavicollis, A. agrarius, and Arvicola terrestris (Koyumidjieva 1974, 1982; Koyumidieva \& Yaneva 1980; Karg 1993; Masan \& StANKo 2005; Krasnow et al. 2010). Sporadically, it was also found in soil and litter (KARG 1993). In Poland, it was previously recorded in the Tatra National Park (CICHOcki 1984; Gwiazdowicz 2010) and the Pieniny Mountains (SKorUPSKi \& GwiazdoWICZ 1996). The presence of this species in the studied soil samples of a broadleaved forest is most certainly accidental.

Family: Rhodacaridae

\section{Stylochirus rovenensis G. et R. Canestrini, 1882}

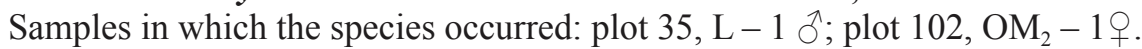
To date, Stylochirus rovenensis was recorded in moss, peatlands, and young pine forests (BREGETOVA 1977). In Poland, the first locality of this species was the peatland reserve 'Wielkie Torfowisko Batorowskie' (KACZMAREK et al. 2006). Our study area in Kwidzyn Forest District is the second locality of this species in Poland.

\section{Family: Parasitidae}

\section{Eugamasus crassitarsis (Halbert, 1923)}

Samples in which the species occurred: plot $102, \mathrm{OM}_{1}-1$ q Eugamasus crassitarsis occurs in litter, arable lands, and pastures on sandy soil (HyATT 1980). In Poland, it was recorded in postindustrial wastelands (MADEJ 2004), arable lands near Warsaw (MichERDZIŃSKi 1969), the soil of a seasonally flooded meadow (KACZMAREK et al. 2010), and in the litter of ash-alder riparian forest Fraxino-Alnetum (KACZMAREK et al. 2012). Our study area is the first locality of this species in the soil of subcontinental broadleaved forest Tilio-Carpinetum.

Acknowledgements: The study was supported by the Ministry of Science and Higher Education, Warsaw, Poland (PhD grant no. N N304 408938).

\section{REFERENCES}

Bogdanowicz W., Chudzicka E., Pilipiuk I., Skibińska E. 2008. Fauna Polski. Charakterystyka i wykaz gatunków [Polish Fauna. Characteristics and list of species]. Vol. III. Muzeum i Instytut Zoologii PAN, Warszawa (in Polish).

BREGETOVA I. G. 1977. Opredelitel obitayushchikh w pochve kleshchei [Identification key to soilinhabiting mites Mesostigmata]. AN SSSR, Leningrad (in Russian).

Cichоскі W. 1984. Akarofauna Tatrzańskiego Parku Narodowego w świetle dotychczasowych badań [Acarofauna of the Tatra National Park in the light of previous investigations]. Par. Nar. i Rez. Przyr. 5: 31-38 (in Polish).

Gwiazdowicz D. J. 2010. Mites (Acari, Mesostigmata) of the Tatra National Park. Acta Sci. Pol., Silv. Colendar. Rat. Ind. Lignar. 9: 5-18.

HaLLAN J. 2011. http://insects.tamu.edu/research/collection/hallan/acari/0ReportHi.htm. Accessed: 19.10.2011. 
Hyatт K. H. 1980. Mites of the subfamily Parasitinae (Mesostigmata: Parasitidae) in the British Isles. British Museum (Natural History), London, Vol. 38.

Kaczmarek S., Marquardt T., Faleńczyk-Koziróg K., Marcysiak K. 2010. Dynamics of mite (Acari) populations in a seasonally flooded meadow on a bank of the Vistula river (Poland), with particular reference to Gamasida. Acta Soc. Zool. Bohem. 74: 55-61.

Kaczmarek S., Marquardt T., Faleńczyk-Koziróg K., Marcysiak K. 2012. Diversity of soil mite communities (Acari) within habitats seasonally flooded by the Vistula River (Ostromecko, Poland). Biological Lett. 49: 97-105.

Kaczmarek S., Marquardt T., Marcysiak K., Badzińska M. 2006. Mites (Acari) of peatlands in the „Wielkie Torfowisko Batorowskie” reserve and the „Bagno Stawek” reserve, with particular reference to the Gamasida. In: Postępy Polskiej Akarologii (Gabryś G., Ignatowicz S., Ed.), pp. 168-173, Wydawnictwo SGGW, Warszawa.

KARG W. 1993. Acari (Acarina), Milben Parasitiformes (Anactinochaeta) Cohors Gamasina Leach. Die Tierwelt Deutschlands 59 (in German).

Kondracki J. 2009. Geografia regionalna Polski [Regional geography of Poland]. Państwowe Wydawnictwo Naukowe, Warszawa (in Polish).

KoyumdIEVA M. I. 1974. A study of mites of the superfamily Gamasoidea (Parasitiformes) on small mammals in the central and eastern Balkan Mountains. Bull. Inst. Zool. Mus. XLI: 229-240 (in Bulgarian).

Koyumdieva M. I. 1982. Gamasoid Mites (Gamasoidea, Parasitiformes) Parasitic on Apodemus sylvaticus L. and Apodemus flavicollis Melch. in Bulgaria. Acta Zool. Bulgar. 20: 69-76 (in Bulgarian).

Koyumdieva M. I., Yaneva V. A. 1980. Studies on Gamasoid Mites (Gamasoidea, Parasitiformes) Found on Small Mammals in the Yambol District. Acta Zool. Bulgar. 15: $43-55$ (in Bulgarian).

Krantz G. W., Walter D. E. 2009. A manual of acarology. Texas Tech University Press.

Krasnov B. R., Matthee S., Lareshi M., Korallo-Vinarskaya N. P., Vinarski M. V. 2010. Cooccurrence of ectoparasites on rodent hosts: null model analyses of data from three continents. Oikos 119: 120-128.

Madej G. 2004. Rozwój zgrupowań roztoczy Mesostigmata (Arachnida, Acari) na nieużytkach poprzemysłowych [Development of communities of mesostigmatid mites (Arachnida, Acari) in areas of postindustrial wastelands]. Wydawnictwo Uniwersytetu Śląskiego, Katowice (in Polish).

MašÁn P., Stanko M. 2005. Mesostigmatic mites (Acari) and fleas (Siphonaptera) associated with nests of mound-building mouse, Mus spicilegus Petényi, 1882 (Mammalia, Rodentia). Acta Parasitol. 50: 228-234.

MicherdZińsKi W. 1969. Die familie Parasitidae Oudemans 1901 (Acarina, Mesostigmata) [Family Parasitidae Oudemans 1901 (Acarina, Mesostigmata)]. PWN, Warszawa (in German).

Skorupski M., Gwiazdowicz D. J. 1996. Roztocze (Acari, Mesostigmata) Pienin. [Mites (Acari, Mesostigmata) of the Pieniny Mountains]. Fragm. Faun. 39: 223-243 (in Polish). 